\title{
The Effects of Deferred Compensation and Performance-based Compensation on Firm Value
}

\author{
Dong Heon Byun ${ }^{\mathrm{a}}$, Jinbae Kim ${ }^{* b}$ and Joon Yong Shin ${ }^{\mathrm{b}}$ \\ ${ }^{a}$ Agricultural and Fishery Marketing Corporation \\ ${ }^{b}$ Korea University
}

\begin{abstract}
This study empirically investigates the effects of two incentive systems: (i) the deferred compensation system, which involves paying lower (higher) compensation than the industry average during employees' early (later) service periods; and (ii) the performance-based compensation system. Empirical results using employee-wage data from Korean firms show that both the deferred compensation system and the performance-based compensation system have positive associations with firm value measured by Tobin's Q. However, the associations between the two types of incentive system and other value-relevant factors are not uniform. While the deferred compensation system contributes to the enhancement of ROA and an improvement in labor productivity, the performance-based compensation system stimulates sales growth.
\end{abstract}

JEL Classifications: J31, M52

Keywords: compensation, incentive, deferred compensation, performance, firm value

\section{Introduction}

Firms are organizations in which agents cooperate with each other and share their organization's output. The interests of the agents are diverse and often in conflict. One of the most critical issues in managing firms is how to coordinate the activities and interests of participating agents. Maximizing firm value by coordinating agents' interests is restricted when information asymmetry exists among agents. When the informed party possesses information that the uninformed party does not and has an incentive to act against the uninformed party, firm value will be negatively affected. Therefore,

\footnotetext{
* Corresponding author: email: jinbae@korea.ac.kr. Acknowledgments: We appreciate the comments and suggestions of an anonymous reviewer and workshop participants at the 2005 Management Accounting Section Conference, $16^{\text {th }}$ Asian-Pacific Conference on International Accounting Issues and Korea University. Jinbae Kim gratefully acknowledges financial support from Korea University and Asian Institute of Corporate Governance.
} 
alleviating such agency costs is an important part of managing firms and maximizing their value.

Various types of incentive system have been used by firms to provide an appropriate degree of motivation to employees, to minimize agency costs, and eventually to improve firm value. This study empirically investigates whether two specific types of incentive system can improve firm value. These types of incentive system are: (i) the deferred compensation system, which pays lower compensation than the industry average during employees' early service periods and higher compensation than the industry average during employees' later service periods; and (ii) the performance-based compensation system. The study also analyzes the effects of these incentive systems on other valuerelevant factors.

Numerous studies have investigated issues related to agency costs. A main focus of previous studies dealing with the agency problem is firm characteristics or the relationship between owners and management. Since Jensen and Meckling (1976), studies on agency theory have investigated the relationship among ownership structure, the agency problem, and firm value (Stulz, 1988; Morck et al., 1988; Chen and Steiner, 2000; and Fan and Wong, 2002); the effects of agency costs on financial decisions such as investment, capital structures, and dividends (Ross, 1977; Grossman and Hart, 1980; and Agrawal and Knoeber, 1996); and the relationship among CEO compensation, corporate governance, and agency costs (Douglas and Santerre, 1990; Kaplan, 1994; and Cho, 1998).

The type and level of agency costs in firms differ, depending on such matters as their ownership structure and governance styles. Agency costs pose problems at all levels of the organization, not just at the level of the CEO, and firm governance style is not the only element that determines agency costs. It is widely believed that various types of agency costs, caused by opportunistic management and employee behavior, exist in firms. Previous studies, however, concentrate on the agency costs at the executive level only. The effectiveness of a particular optimal incentive system depends on a firm's characteristics and environments, but empirical studies of this issue have been rare. This study examines the ability of two particular incentive systems - which are applied not only to upper management but also to mid- and lower-level employees - to increase firm value.

An analysis of employee-wage data of Korean firms covering 20 years reveals that both the deferred compensation system and the performance-based compensation system have positive relationships with firm value measured by Tobin's Q. However, the associations between the two types of incentive system and other value-relevant factors are not uniform. While the deferred compensation system contributes to the enhancement of return on assets (ROA) and an improvement in labor productivity, the performance-based compensation system stimulates sales growth. These results imply that Korean firms use the performance-based compensation system mainly to increase the size of firms rather than to improve operational efficiency.

This study differs from previous studies in at least two ways. First, while the previous studies use macro data collected primarily from public sources, including financial statements and disclosures, this study uses actual employee-wage data for employees at all levels and performance-based compensation data covering 20 years. 
Second, this study examines the effects of incentive systems on the major factors of firm value, while other studies focus on firm value only. Analyzing their effects on various factors of firm value shows that incentive systems improve firm value in different ways, and can help identify the way firm value is improved by incentive systems.

\section{Theory and Hypotheses}

Agency theory treats a firm as a set of contracts among agents who participate in the firm to maximize their utilities. Agency costs in the context of the employment contract occur when the informed party (the employee) has an incentive to act against the uninformed party (management). Management needs to design effective employment contracts to minimize agency costs arising from the agent's private information set and opportunistic behavior. Various types of employment contracts have been suggested and used to minimize the threat of moral hazard.

\subsection{Deferred Compensation and Bonding}

Since the 1970s, some firms in the U.S. have adopted employment contracts requiring employees to deposit a bond to prevent moral hazard and to guarantee performance. The bond, which is forfeited when contracts are broken, is designed to prevent opportunistic, dysfunctional behavior. The bond should be large enough to offset the expected gain from cheating even when the probability of getting caught is small. However, the problem with such a bond system in practice is that it is usually unfeasible to obtain a sufficiently large bond from employees.

An employment contract that can present incentives similar to posting a bond is a deferred compensation contract, as Lazear $(1979,1998)$ and Milgrom and Roberts (1992) suggest. Under this compensation structure, a firm pays employees less than the value of what employees produce in their early employment periods. In their later employment periods, the firm pays more than the value of what they produce and what they can be paid elsewhere. The present value of employees' lifetime earnings under this compensation structure would not be affected and therefore the value of this contract to employees would not be diminished. The costs to the firms would be similarly unaffected. The high wage promised in future years serves as a bond that can be forfeited in the case of evidence of moral hazard. The difference between the low wage and the marginal productivity in the early employment period can be regarded as an insurance premium to ensure honest working behavior.

It is claimed that the deferred compensation system also has a screening function in addition to its incentive role (Lazear, 1981, 1998). High staff turnover is costly, especially for firms that invest a significant amount in training. In such circumstances, under conditions of information asymmetry, screening schemes to attract workers who are less inclined to change jobs are desirable. If a firm pays wages that are relatively lower than the market average in the early stages of employment and pays higher wages than the market average in the later stages of employment, workers who would tend to 
remain with a firm over an extended period of time will choose to work in the firm as they would prefer such an employment contract. ${ }^{1}$

While the deferred compensation system might help to alleviate agency costs, certain conditions would have to be met for it to work properly. For example, employees should be required to retire at a certain age in order to sustain the scheme. Otherwise, if some senior employees continued to work under a deferred compensation system that paid higher than the value of their outputs, the costs to the firm would exceed the benefits of adopting the scheme.

The deferred compensation system also needs to make credible the promise of higher payment in later employment years. If there is a possibility that a firm may break the promise of paying more in later employment years, potential employees would not tolerate lower payments in the early years. There are several ways to make the promise credible. The good reputation of the firm may ensure the credibility of the promise. A seniority rule with regard to layoffs that a firm must lay off all junior employees before it can lay off a senior employee might also work, as Milgrom and Roberts (1992) claim. A life-time employment guarantee with a required retirement at a certain age would make the promise very credible. Because these conditions, and possibly other conditions, need to be met if a deferred compensation system is to be effective, not all firms can use such a system. Thus, it would be interesting to empirically investigate the effect of the deferred compensation system on firm value. ${ }^{2}$

The above discussion leads to the argument that the bonding effects and screening function of the deferred compensation system will have a positive effect on the value of a firm. To carry out empirical analyses, firm value needs to be measured. Following the numerous previous studies, Tobin's Q, defined as the ratio of the market value of the firm divided by the replacement cost of its total assets, is chosen as a proxy for overall firm value (Lindenberg and Ross, 1981; Mehran, 1995; Bauer et al., 2003). So the following hypothesis is proposed:

H 1-1: There is a positive relationship between the adoption of the deferred compensation system and Tobin's Q.

While Tobin's Q is widely used as a proxy for firm value in the literature, whether it is a suitable proxy for firm value is a subject of continuing debate. To measure Tobin's $Q$ by the way it is defined is not an easy task because it involves estimating the replacement costs of assets. In addition, many argue that it is a proxy for a firm's growth opportunity rather than for firm value. Because Tobin's Q reflects the cumulative effects of previous and current performance over time, it is not particularly sensitive to recent change in firm value, unlike some other performance measures.

To mitigate the measurement problems of Tobin's Q and better understand various aspects of firm value enhancement processes, this study further investigates the effect of

\footnotetext{
${ }^{1}$ Paying wages at the same level as the worker's marginal productivity is, on average, the same as paying the market average if the workers attracted to each firm have a similar level of productivity.

${ }^{2}$ An alternative approach would be to investigate the effects of the deferred compensation structures on agency costs. While several studies have tried to directly measure agency costs, this approach is not chosen because agency costs could not be measured with sufficient accuracy.
} 
the deferred compensation system on four other factors that are deemed to be relevant to firm value: return on assets, sales growth, productivity, and expenses.

Return on assets is a measure of accounting profitability that is used as a performance measure by numerous studies. As firm value can be viewed as a sum of discounted future cash flows, and as future cash flows are strongly associated with accounting earnings, there is an obvious relation between accounting profitability and firm value. Because firm value can be increased by increasing cash flows, either increases in sales revenue or reductions in expenses can improve firm value. Sales growth is also frequently used as a proxy for future investment opportunities, which are a major part of firm value. Productivity is also a critical factor affecting firm value as it can increase future earnings and cash flows.

These four variables are regarded by many textbooks and previous studies as factors critically relevant to firm value. Analyzing the relation between the deferred compensation system and these factors can provide supplementary evidence that deferred compensation can improve firm value. Furthermore, this additional analysis might provide more concrete information on how firm value can be improved. The operation of a firm consists of different types of activity, so firm value can be increased through many different paths. Each of the four factors analyzed in this study may represent one way of improving firm value (even though there are many more than these four ways to improve firm value). Analyzing the relation between an incentive system and value-relevant factors can help identify the way the incentive system improves firm value. For example, an incentive system might increase firm value by improving sales revenue without affecting expenses.

The above discussion leads us to the following hypotheses:

H 1-2: There is a positive relationship between the adoption of the deferred compensation system and return on assets.

H 1-3: There is a positive relationship between the adoption of the deferred compensation system and sales growth.

$\mathrm{H} \mathrm{1-4:} \mathrm{There} \mathrm{is} \mathrm{a} \mathrm{positive} \mathrm{relationship} \mathrm{between} \mathrm{the} \mathrm{adoption} \mathrm{of} \mathrm{the} \mathrm{deferred}$ compensation system and labor productivity.

H 1-5: There is a negative relationship between the adoption of the deferred compensation system and the level of expenses.

\subsection{The Performance-based Compensation System}

The performance-based compensation system is one of the most often used incentive systems. It screens highly productive employees and also provides incentives to increase efforts. Performance-based compensation can be of various types, such as profit sharing, different incentive systems for different departments, annual salary systems, and stock option schemes. A compensation system based on performance evaluation can attract competent applicants, reduce the number of high-productivity employees seeking early retirement, and induce workers to increase their efforts while containing problems of moral hazard. The theoretical effect of such a scheme would be an increase in firm value. 
Tobin's $\mathrm{Q}$ is chosen as a proxy to measure firm value, and the following hypothesis is proposed:

H 2-1: There is a positive relationship between the adoption of the performancebased compensation system and Tobin's Q.

The relations between the performance-based compensation system and four valuerelevant factors - return on assets, sales growth, productivity, and expenses-are similarly investigated. This additional analysis is particularly useful because the effectiveness of the performance-based compensation system is sensitive to the environment in which it is used. It is well known that the performance-based compensation system is effective when the income effect of the employees' efforts is high, when employees have relatively low risk-aversion, when performance can be accurately measured, and when the probability of employee productivity improvement is high. Therefore, such a system cannot be effectively applied to all firms with the certainty that the risk of moral hazard will be reduced. Firms for which this system is unsuitable would adopt systems such as the deferred compensation system described above or other, more traditional methods such as the direct control system.

The above discussion leads to the following hypotheses:

$\mathrm{H}$ 2-2: There is a positive relationship between the adoption of the performancebased compensation system and return on assets.

$\mathrm{H}$ 2-3: There is a positive relationship between the adoption of the performancebased compensation system and sales growth.

$\mathrm{H} \mathrm{2-4:} \mathrm{There} \mathrm{is} \mathrm{a} \mathrm{positive} \mathrm{relationship} \mathrm{between} \mathrm{the} \mathrm{adoption} \mathrm{of} \mathrm{the} \mathrm{performance-}$ based compensation system and labor productivity.

H 2-5: There is a negative relationship between the adoption of the performancebased compensation system and the level of expenses.

\section{Sample and Data}

Every year, the Ministry of Labor of Korea surveys labor conditions in Korea, including wages and labor hours. The sample firms for this study are initially drawn from the 1999 and 2000 surveys, which cover 1,080 firms. Of these 1,080 firms in the initial sample, 834 firms that were not listed on the Korea Stock Exchange in the sample period are excluded because their accounting data are not available from the KIS-FAS database. Three firms that were merged with other firms or were designated as having stocks of administrative issue are excluded because their unusual circumstances in their operations might adversely affect the homogeneity of the sample firms. ${ }^{3}$ Sixteen financial firms are excluded because they might have different wage structures and

\footnotetext{
${ }^{3}$ The key criteria for the designation of stocks as administrative issue by the Listing Regulation 42-2 of the Korea Stock Exchange are: (i) cases where the CPA audit opinion on the latest fiscal year of a listed corporation is qualified due to limits placed on the scope of the audit; (ii) suspension of business operations; (iii) nonpayment of debt or suspension of transactions with banks; and (iv) impairment of the capital stock.
} 
characteristics from those of manufacturing firms. Finally, three firms with negative net book values of equity are excluded following Core et al. (2003).

Based on these criteria, a sample of 215 firms is selected. The industry distribution of the sample is shown in Table 1.

Table 1

Industrial Distribution of Sample Firms

\begin{tabular}{|l|c|}
\hline \multicolumn{1}{|c|}{ Industry } & Number of Firms \\
\hline Food, beverages & 20 \\
\hline Textiles, apparel & 14 \\
\hline Pulp, paper & 7 \\
\hline Petroleum, chemicals, rubber & 43 \\
\hline Pharmaceuticals & 15 \\
\hline Non-metallic minerals & 9 \\
\hline Basic metals & 11 \\
\hline Machinery \& equipment & 21 \\
\hline $\begin{array}{l}\text { Electronic communication equipment, } \\
\text { electrical machinery, precision machinery }\end{array}$ & 39 \\
\hline Construction & 11 \\
\hline Wholesale, retail & 8 \\
\hline $\begin{array}{l}\text { Service (electricity \& gas, transportation, } \\
\text { telecommunications) }\end{array}$ & 12 \\
\hline Fishery, mining & 5 \\
\hline Total & 215 \\
\hline
\end{tabular}

The wage data are obtained from the Survey Reports on Wage Structure of the Ministry of Labor, as stated earlier. ${ }^{4}$ The wage data obtained for this study are the fixed monthly salary and bonus for male workers. ${ }^{5}$

Accounting and financial data for the sample firms are obtained from the KISFAS database of the Korea Information Service, while shareholding and ownership information are obtained from the Data Analysis Retrieval and Transfer System (DART) of the Financial Supervisory Service and the TS2000 Database of the Korea Listed Companies Association. Information on performance-based compensation is gathered by telephone or personal-visit interviews with managers in HR departments.

\footnotetext{
${ }^{4}$ The wage data are not in the public domain. The authors appreciate that the Korean Ministry of Labor allowed use of the confidential wage data for this study.

${ }^{5}$ While wages of female workers are not available, the exclusion would not affect the main results of this study. The wage structure of female workers in Korea is qualitatively different from that of male workers. Many female workers are part-time employees and their wages are substantially lower than those of males. In addition, the proportion of female workers is low and varies substantially across firms.
} 


\section{Variable Measurement and Model}

Firm Value: Tobin's Q, defined as the ratio of the market value of the firm divided by the replacement cost of its total assets, is chosen as a proxy for overall firm value in this study. Because it is difficult to measure the replacement cost of assets accurately, this study follows the common practice of measuring Tobin's Q as (market value of equity plus the book value of debt) divided by (book value of total assets) (Bai et al., 2003; Black et al., 2006). The market value of equity is calculated using the share price at the end of the year.

Other Value-relevant Factors: Other factors affecting firm value also need to be measured. Return on assets is measured by net income plus after tax interest expense divided by average total assets, where a tax rate of $28 \%$ is assumed. Sales growth is measured as the growth rate of sales revenue. The size of expenses is measured as the natural $\log$ of the cost of goods sold plus selling and administrative expenses. Finally, labor productivity is measured as value added per employee divided by average total assets. The value added is measured as the sum of income before extraordinary items, salaries and wages, rent, taxes, depreciation, and net interest expenses. ${ }^{6}$ Salaries and wages, rent, taxes, and depreciation should include not only the period costs that are expensed and recorded in the selling and administrative section of the current period income statement, but also the product costs that are initially capitalized as a part of inventory. Therefore, each of the four items is calculated by adding the expense amount from the selling and administrative section and the portion included in the costs of goods sold. $^{7}$

Deferred Compensation: The first independent variable, deferred compensation, is measured using a dummy variable (DCDUM). In those firms that adopt the deferred compensation system, wage would increase more slowly than the industry average in the early period and faster than the industry average in the later period. When wage is regressed on the length of the service period for which an employee has served in the firm, the slope coefficient of a firm adopting the deferred compensation system would be lower (higher) than the industry coefficient in the early (later) period. So this study regards those firms with lower slope coefficients than the industry coefficient in the early period and higher slope coefficients than the industry coefficient in the later period as the firms adopting the deferred compensation system.

To measure DCDUM, the total period covering 20 years needs to be divided into two periods; an "early" service period and a "later" service period. Theoretically, the cut-off point between the early period and the later period is the year when the wage of a firm with the deferred compensation system catches up and first matches the industry average wage. While firms may have different cut-off years, measuring a cut-off year for each firm would complicate the measurement process and increase measurement errors. Most HR experts and managers who were interviewed for this study indicate that the cut-

\footnotetext{
${ }^{6}$ The definition is used widely by major institutions in Korea. For more details, see Financial Statement Analysis for 2005 (2006) published by The Bank of Korea or The Analysis of the Value Added of Listed Companies (2006) by Korean Productivity Center.

${ }^{7}$ Salaries and wages, rent, taxes, and depreciation included in the costs of goods sold are obtained from the statement of costs of goods manufactured. The statement of costs of goods manufactured is a supplementary financial statement in Korea, which provides detailed information on the costs of goods sold.
} 
off year for most Korean firms is the $5^{\text {th }}$ or $6^{\text {th }}$ year. In the early service period, Korean firms would focus on investment and training, and employees' outputs would tend to be lower than what they are paid for. Based on the interview results, the first service period is determined as the period from the $2^{\text {nd }}$ to the $6^{\text {th }}$ year and the second service period as the period from the $7^{\text {th }}$ to the $20^{\text {th }}$ year. The wages for the first year are excluded from the analysis because they contain many irregularities. For example, many of them do not cover the full 12-month compensation.

Values for DCDUM are specifically determined as follows. Wage data for the sample firms covering 20 years are divided into an early service period (the $2^{\text {nd }}$ to the $6^{\text {th }}$ year) and a later service period (the $7^{\text {th }}$ to the $20^{\text {th }}$ year). The wage regressions for each firm and industry are estimated for both the early period and later period. Those firms that have lower slope coefficients than the industry coefficient during the early period and higher slope coefficients than the industry coefficient during the later period are classified as deferred compensation firms, and are assigned a value of 1 for DCDUM. All other firms are assigned a value of 0 for DCDUM.

A critical underlying assumption of measuring the deferred compensation system in this way is that the total compensation level over the entire employment period is the same for all firms, or the total compensation levels are at least within a comparable range. If the compensation level of a firm is considerably higher than the industry average, a lower slope coefficient of the wage regression in the early period and a higher slope coefficient in the later period do not necessarily indicate the adoption of the deferred compensation system. It is because that a firm can pay high compensation throughout all the employment periods. Such a firm would not claim that it uses the deferred compensation system.

To ensure that the compensation levels of the sample firms are within a comparable range, the analyses in this study are mainly performed for an "adjusted" sample that excludes firms that provide an average pay of 30 percent more or 30 percent less than the industry average (called "extreme firms").

Performance-based Compensation: The second independent variable, adoption of the performance-based compensation system, is also measured using a dummy variable (PCDUM). A value of 1 is assigned to those firms that employ performance pay systems. To decide if a firm employs a performance pay system, managers in the HR department were interviewed. Most of the interviewed managers claim that their firms adopt some form of the performance-based pay system. However, many of the systems turn out to be only nominal and the payments received are regarded by employees as a portion of their regular salary rather than as a compensation for good (or bad) performance. The incentive effects of such payments may not be material. To capture the intended incentive effects, the performance-based compensation system in this paper is limited to two types. The first type comprises compensation systems that involve profit-sharing schemes whose rules and details are predetermined at the start of each year and carried out rigorously. The second type consists of compensation systems that actually make different incentive payments to each individual or each team unit. The interviewed managers were asked specifically if their firms had adopted the above-mentioned compensation systems. When they confirm this and provide supporting evidence, a value of 1 is assigned for PCDUM. All other firms are assigned a value of 0 for PCDUM. 
Control Variables: Since firm value is possibly influenced by factors other than wage structure and a compensation system based on performance, we control these factors in the study. We control firm size and industry since they create different environments for agency costs and therefore affect firm value. Jensen and Meckling (1976) and Grossman and Hart (1980) claim that liability provides a source of agency costs. It is also claimed that high liability tends to induce income-increasing behavior of management and suppress investment. Therefore, capital structure is another factor that may affect firm value.

Prior studies such as Jensen and Meckling (1976) and Morck et al. (1988) investigated the relationship between agency costs and ownership structure, and documented that the ownership ratios of specific groups have significant impacts on firm value. To control these effects, this paper includes in the regression ownership by the largest shareholder and related parties, institutional ownership, and foreign ownership.

Model: In summary, the following cross-sectional model is used to test the hypotheses:

$$
\begin{aligned}
\text { DEPVAR }_{j t}= & \beta_{0}+\beta_{1} \text { DCDUM }_{j t}+\beta_{2} \text { PCDUM }_{j t} \\
& +\beta_{3} \text { LEVER }_{j t}+\beta_{4} \text { LNSALES }_{j t}+\beta_{5} \text { INSTI }_{j t}+\beta_{6} \text { FOREN }_{j t} \\
& +\beta_{7} O W N_{j t}+\sum_{k=1}^{12} \beta_{8 k} I D U M_{j t k}+\varepsilon_{j t}
\end{aligned}
$$

where

DEPVAR: dependent variables

Tobin's Q: $\quad$ (market value of equity + book value of debt)

$\div$ book value of total assets

ROA: (net income + interest expense, net of taxes) ${ }^{8}$

$\div$ average total assets

GROWTH: $\quad$ growth rate of sales revenue

LNEXPENSE: $\quad$ ln (cost of goods sold + selling \& administrative expenses)

PRODT: $\quad$ value added per employee divided by average total assets

DCDUM: 1 if the firm adopts a deferred compensation system, 0 otherwise

PCDUM: $\quad 1$ if the firm adopts a performance-based compensation system, 0 otherwise

LEVER: total liability divided by total assets

LNSALES: $\ln$ (sales revenue)

INSTI: proportion of shares owned by institutional investors

${ }^{8} 28 \%$ of the tax rate is used to calculate ROA. 
FOREN: proportion of shares owned by foreign investors

OWN: $\quad$ proportion of shares owned by largest shareholders and related parties

IDUM: industry dummies

\section{Empirical Results}

\subsection{Descriptive Statistics}

From the initial sample of 215 firms, firms that provide an average pay of $30 \%$ more or $30 \%$ less than the industry average (called "extreme firms") are excluded. This procedure excludes 60 firms from the 1999 data and 53 firms from the 2000 data. The number of firms in the sample is reduced to 155 for 1999 and 162 for 2000 . The results from the "adjusted" sample that excludes "extreme firms" are hereafter reported in the tables as the main results and the full sample results will be discussed when warranted. ${ }^{9}$

Table 2 presents the descriptive statistics for the adjusted sample. The average of Tobin's Q is 0.9582 in 1999 and 0.7797 in 2000 . The reported Tobin's Q is similar to that of other studies. ${ }^{10}$ A Tobin's Q lower than 1 means that the firm's market value, which is supposed to include the value of intangible assets and future investment opportunities, is less than the firm's book value. Such a low value may imply undervaluation, private benefits for large shareholders, or overinvestment. ${ }^{11}$

Table 2

Descriptive Statistics of Variables

\begin{tabular}{|l|c|c|c|c|c|c|}
\hline \multirow{2}{*}{ Variable } & \multicolumn{3}{|c|}{1999} & \multicolumn{3}{c|}{2000} \\
\cline { 2 - 7 } & Mean & Median & Std.Dev & Mean & Median & Std.Dev \\
\hline Tobin's $Q$ & 0.9582 & 0.8087 & 0.5900 & 0.7797 & 0.7417 & 0.2773 \\
\hline ROA & 0.0618 & 0.0601 & 0.0621 & 0.0575 & 0.0485 & 0.1166 \\
\hline GROWTH & 0.0859 & 0.0325 & 0.2888 & 0.1365 & 0.1020 & 0.2737 \\
\hline LNEXPENSE & 19.7268 & 19.4135 & 1.5031 & 19.7088 & 19.4683 & 1.4549 \\
\hline PRODT & 0.0001 & 0.0001 & 0.0005 & 0.0002 & 0.0001 & 0.0004 \\
\hline DCDUM & 0.2774 & 0.0000 & 0.4491 & 0.3456 & 0.0000 & 0.4770 \\
\hline PCDUM & 0.2387 & 0.0000 & 0.4276 & 0.3210 & 0.0000 & 0.4683 \\
\hline LEVER & 0.5491 & 0.5505 & 0.1738 & 0.5305 & 0.5315 & 0.1674 \\
\hline LNSALES & 19.8042 & 19.5056 & 1.5048 & 19.7886 & 19.5532 & 1.4608 \\
\hline
\end{tabular}

\footnotetext{
${ }^{9}$ The average size of the firms, measured by sales revenue, in the adjusted sample is bigger than that of the full sample in 1999 and smaller than that of the full sample in 2000. This indicates that no systematic shift in firm size occurs when "extreme firms" are excluded. All the other statistics of the adjusted sample are also similar to those of the full sample. Also, when all the analyses are repeated with the full sample that includes "extreme firms", the results are not qualitatively different from the results reported in this paper.

${ }^{10}$ For example, Black et al. (2006) report that the average Tobin's Q of Korean firms was 0.85 in 2001.

${ }^{11}$ See Joh (2003) for supporting evidence.
} 


\begin{tabular}{|l|l|l|l|l|l|l|}
\hline INSTI & 0.1021 & 0.0730 & 0.1021 & 0.0861 & 0.0445 & 0.1119 \\
\hline FOREN & 0.0862 & 0.0320 & 0.1289 & 0.0905 & 0.0270 & 0.1433 \\
\hline OWN & 0.3452 & 0.3240 & 0.1511 & 0.3743 & 0.3765 & 0.1614 \\
\hline Sample size & \multicolumn{7}{|c|}{155} & \multicolumn{3}{|c|}{162} \\
\hline
\end{tabular}

Definitions of Variables

Tobin's $Q \quad$ (market value of equity plus book value of debt) divided by book value of total assets

$R O A \quad$ (net income plus interest expense, net of tax) divided by average total assets

GROWTH growth rate of sales revenue

LNEXPENSE In (cost of goods sold + selling \& administrative expenses)

$P R O D T \quad$ value added per employee divided by average total assets

DCDUM 1 if a firm adopts a deferred compensation system, 0 otherwise

PCDUM 1 if a firm adopts a performance-based compensation system, 0 otherwise

LEVER total liability divided by total assets

LNSALES $\quad \ln$ (sales revenue)

INSTI proportion of shares owned by institutional investors

FOREN proportion of shares owned by foreign investors

$O W N \quad$ proportion of shares owned by largest shareholders and related parties

Forty-three firms out of 155 adopt the deferred compensation system in 1999 and 56 firms out of 162 in 2000, making the average DCDUM 0.2774 in 1999 and 0.3456 in 2000. The performance-based compensation system is adopted by 37 firms in 1999 and 52 firms in 2000, making the average PCDUM 0.2387 in 1999 and 0.3210 in 2000. The numbers of firms that adopt both compensation systems are 9 (5.8\%) in 1999 and 20 $(12.3 \%)$ in 2000 .

Table 3 presents Pearson correlation coefficients for the selective variables in the model. Tobin's Q is significantly positively correlated with DCDUM, PCDUM, and FOREN. It provides a preliminary support for the positive impacts of the deferred compensation and the performance-based compensation on firm value. Firm size has significant positive correlations with leverage, institutional ownership, and foreign ownership. Leverage is significantly negatively correlated with institutional ownership and largest shareholder ownership.

Table 3

Pearson Correlation Matrix of Variables

\begin{tabular}{|c|c|c|c|c|c|c|c|c|}
\hline Variables & Tobin's $Q$ & DCDUM & PCDUM & LEVER & LNSALES & INSTI & FOREN & OWN \\
\hline Tobin's $Q$ & 1.0 & $0.161 * *$ & $0.199 * * *$ & 0.065 & $0.129 *$ & 0.010 & $0.240^{* * *}$ & -0.085 \\
\hline DCDUM & $0.134 *$ & 1.0 & 0.084 & 0.094 & 0.050 & 0.076 & 0.014 & 0.037 \\
\hline PCDUM & $0.122^{*}$ & 0.050 & 1.0 & -0.085 & 0.056 & 0.071 & 0.086 & 0.005 \\
\hline LEVER & -0.010 & -0.002 & 0.092 & 1.0 & $0.364 * * *$ & $-0.120^{*}$ & -0.096 & -0.080 \\
\hline LNSALES & 0.039 & 0.001 & 0.024 & $0.227 * * *$ & 1.0 & $0.242^{* * *}$ & $0.399 * * *$ & 0.100 \\
\hline INSTI & -0.086 & -0.097 & -0.086 & $-0.146^{* *}$ & $0.273^{* * *}$ & 1.0 & 0.071 & 0.027 \\
\hline FOREN & $0.219 * * *$ & 0.024 & 0.108 & -0.100 & $0.303 * * *$ & $0.116^{*}$ & 1.0 & 0.036 \\
\hline OWN & -0.053 & 0.055 & 0.074 & $-0.177 * *$ & -0.016 & $-0.131^{*}$ & $0.145^{* *}$ & 1.0 \\
\hline
\end{tabular}


The upper-right triangle represents the correlation coefficient for 2000 and the lower-left triangle represents the correlation coefficient for 1999.

$* * *, * *$, and $*$ indicate statistical significance at the $1 \%, 5 \%$, and $10 \%$ levels, respectively.

See Table 2 for definitions of variables.

\subsection{Regression Results for Tobin's $Q$}

The effects of the deferred compensation system and the performance-based compensation system on firm value are presented in Table 4. The regression results show that the deferred compensation system has a significant and consistent effect on firm value. The coefficients of DCDUM are positive in 1999, 2000 and the pooled period. DCDUM has a significant positive relationship with Tobin's Q at the 10\% level in 1999 (a coefficient of 0.141 and a $t$-value of 1.909) and in the pooled period (a coefficient of 0.072 and a $t$-value of 1.673). This result therefore provides statistical support for Hypothesis 1-1. As higher compensation than the industry average in the later stages of employees' careers acts as a bond that reduces opportunistic behavior, the adoption of the deferred compensation system reduces agency costs and increases firm value.

Table 4

The Effect of the Deferred Compensation System and the

Performance-based Compensation System on Firm Value

Tobin's $Q=\beta_{0}+\beta_{1} D C D U M+\beta_{2} P C D U M+\beta_{3} L E V E R+\beta_{4} L N S A L E S$

$$
+\beta_{5} I N S T I+\beta_{6} F O R E N+\beta_{7} O W N+\sum \beta I D U M+\varepsilon
$$

\begin{tabular}{|c|c|c|c|}
\hline \multirow{2}{*}{ Variable } & \multicolumn{3}{|c|}{ Period } \\
\hline & 1999 & 2000 & Pooled \\
\hline Intercept & $\begin{array}{c}1.782 \\
(3.148)^{* * *}\end{array}$ & $\begin{array}{c}0.850 \\
(2.348)^{* *}\end{array}$ & $\begin{array}{c}1.413 \\
(4.119)^{* * * *}\end{array}$ \\
\hline$D C D U M$ & $\begin{array}{c}0.141 \\
(1.909) *\end{array}$ & $\begin{array}{c}0.053 \\
(1.210)\end{array}$ & $\begin{array}{c}0.072 \\
(1.673)^{*}\end{array}$ \\
\hline PCDUM & $\begin{array}{c}0.210 \\
(2.626)^{* * *}\end{array}$ & $\begin{array}{c}0.103 \\
(2.244)^{* *}\end{array}$ & $\begin{array}{c}0.124 \\
(2.739)^{* * * *}\end{array}$ \\
\hline LEVER & $\begin{array}{c}0.287 \\
(1.283)\end{array}$ & $\begin{array}{c}0.130 \\
(0.853)\end{array}$ & $\begin{array}{c}0.279 \\
(2.031)^{* *}\end{array}$ \\
\hline LNSALES & $\begin{array}{c}-0.055 \\
(-1.855)^{*}\end{array}$ & $\begin{array}{c}-0.007 \\
(-0.374)\end{array}$ & $\begin{array}{c}-0.037 \\
(-2.066)\end{array}$ \\
\hline INSTI & $\begin{array}{c}-0.001 \\
(-0.200)\end{array}$ & $\begin{array}{c}0.001 \\
(0.227)\end{array}$ & $\begin{array}{c}0.001 \\
(0.346)\end{array}$ \\
\hline FOREN & $\begin{array}{c}0.008 \\
(2.893)^{* * *}\end{array}$ & $\begin{array}{c}0.004 \\
(2.704)^{* * *}\end{array}$ & $\begin{array}{c}0.006 \\
(3.856)^{* * *}\end{array}$ \\
\hline$O W N$ & $\begin{array}{c}-0.002 \\
(-1.460)\end{array}$ & $\begin{array}{c}-0.001 \\
(-0.781)\end{array}$ & $\begin{array}{c}-0.002 \\
(-1.756)\end{array}$ \\
\hline
\end{tabular}




\begin{tabular}{|l|c|c|c|}
\hline IDUM & Yes & Yes & Yes \\
\hline Adj- $R^{2}$ & 0.208 & 0.172 & 0.179 \\
\hline F-value & $3.097^{* * *}$ & $2.703^{* * *}$ & $4.541^{* * *}$ \\
\hline
\end{tabular}

$* * *, * *$, and $*$ indicate statistical significance at the $1 \%, 5 \%$, and $10 \%$ levels, respectively. See Table 2 for definitions of variables.

The $t$-values are in parentheses.

Table 4 also shows the effect of the performance-based compensation system on firm value. The coefficients of PCDUM are 0.210 with a $t$-value of 2.626 in $1999,0.103$ with a $t$-value of 2.244 in 2000, and 0.124 with a $t$-value of 2.739 in the pooled period. They are significant at the $1 \%$ level in 1999 and in the pooled period, and are significant at the $5 \%$ level in 2000. These results are consistent with the hypothesis that the adoption of the performance-based compensation system has a positive effect on firm value.

Foreign ownership (FOREN) is found to have a positive relationship with firm value that is significant at the $1 \%$ level in all the three periods. The coefficients of OWN - largest shareholder ownership - are negative in all three periods even though they are not statistically significant. Recently, there has been much interest in corporate governance in Korea. Foreign ownership is generally believed to be associated with good corporate governance because it can provide better monitoring. Ownership by the largest shareholder and related parties is, by the same logic, regarded as a bad signal for corporate governance. The regression results in Table 4 are consistent with this notion.

F-values are 3.097, 2.703, and 4.541 in 1999, 2000, and the pooled period, respectively. They are all statistically significant at the $1 \%$ level. Adjusted R squares are $0.208,0.172$, and 0.179 in 1999,2000 , and the pooled period, respectively. There is no evidence of either autocorrelation or multicollinearity. ${ }^{12}$

The coefficients of regressions using dummy variables suggest how much improvement in Tobin's Q can be achieved on average by adopting incentive systems. The coefficient of DCDUM is 0.072 in the pooled period, which implies that those firms that adopt the deferred compensation system would on average improve their Tobin's Q by that amount. The coefficient of PCDUM is 0.124 in the pooled period, which implies that those firms that adopt the performance-based compensation system would on average improve their Tobin's Q by that amount. Those firms that adopt both compensation systems would increase their Tobin's Q by 0.196 . Such increases in Tobin's Q are substantial given that the average Tobin's Q of all firms is 0.8794 in the pooled period.

The results in Table 4 support the proposition that the deferred compensation system and the performance-based compensation system are used to control employee moral hazard and to improve the value of Korean firms. The impact of adoption of the deferred compensation system or performance-based compensation system on firm value is not only statistically significant but also economically meaningful.

${ }^{12}$ The Durbin-Watson statistic is 2.283 and 2.061 in 1999 and 2000, respectively, and the variance inflation factor is below 2.0. 


\subsection{Regression Results for Return on Assets, Sales Growth, Labor Productivity, and} Expenses

The previous analysis investigated the effects of incentive systems on Tobin's Q, a proxy for firm value in general. Firm value is determined by many factors and increases in firm value can be accomplished through different paths. For example, firm value can be increased by sales increases without changing productivity. Or it can be increased by cost reduction without increases in sales revenue. To investigate the process of firm value increase by the two incentive systems, this study examines the relationship between the two incentive systems and four value-relevant factors that are often associated with firm value, namely return on assets, sales growth, labor productivity, and expenses. Four individual regression equations are estimated with each of the four factors as a dependent variable and the deferred compensation system and performancebased compensation system as the independent variables.

Table 5 presents the regression results with value-relevant factors as dependent variables. The reported results are for the pooled period. The result for Tobin's Q, which is reported in the far left column of Table 5, is reported again for easy comparison.

Table 5

The Effect of the Deferred Compensation System and the

Performance-based Compensation System on

Return on Assets, Sales Growth, Labor Productivity, and Expenses

$$
\begin{aligned}
\text { Dep Var }= & \beta_{0}+\beta_{1} D C D U M+\beta_{2} P C D U M+\beta_{3} L E V E R+\beta_{4} L N S A L E S \\
& +\beta_{5} I N S T I+\beta_{6} F O R E N+\beta_{7} O W N+\sum \beta I D U M+\varepsilon
\end{aligned}
$$

\begin{tabular}{|c|c|c|c|c|c|}
\hline \multirow{2}{*}{$\begin{array}{l}\text { Independent } \\
\text { Variable }\end{array}$} & \multicolumn{5}{|c|}{ Dependent Variables } \\
\hline & Tobin's $Q$ & $R O A$ & GROWTH & PRODT & LNEXPENSE \\
\hline Intercept & $\begin{array}{c}1.413 \\
(4.119)^{* * *}\end{array}$ & $\begin{array}{c}0.038 \\
(1.203)\end{array}$ & $\begin{array}{c}0.012 \\
(0.076)\end{array}$ & $\begin{array}{c}0.002 \\
(13.858)^{* * * *}\end{array}$ & $\begin{array}{c}0.240 \\
(2.530)^{* *}\end{array}$ \\
\hline$D C D U M$ & $\begin{array}{c}0.072 \\
(1.673)^{*}\end{array}$ & $\begin{array}{c}0.007 \\
(1.756)^{*}\end{array}$ & $\begin{array}{c}0.024 \\
(1.226)\end{array}$ & $\begin{array}{c}0.001 \\
(1.011)\end{array}$ & $\begin{array}{c}-0.008 \\
(-0.821)\end{array}$ \\
\hline PCDUM & $\begin{array}{c}0.124 \\
(2.739)^{* * *}\end{array}$ & $\begin{array}{c}-0.002 \\
(-0.372)\end{array}$ & $\begin{array}{c}0.044 \\
(2.162)^{* *}\end{array}$ & $\begin{array}{c}0.001 \\
(0.292)\end{array}$ & $\begin{array}{c}-0.003 \\
(-0.265)\end{array}$ \\
\hline LEVER & $\begin{array}{c}0.279 \\
(2.031)^{* *}\end{array}$ & $\begin{array}{c}-0.047 \\
(-3.301)^{* * *}\end{array}$ & $\begin{array}{c}-0.002 \\
(-0.040)\end{array}$ & $\begin{array}{c}-0.001 \\
(-4.718) * * *\end{array}$ & $\begin{array}{c}0.118 \\
(3.727)^{* * *}\end{array}$ \\
\hline LNSALES & $\begin{array}{c}-0.037 \\
(-2.066)^{* *}\end{array}$ & $\begin{array}{c}0.001 \\
(0.761)\end{array}$ & $\begin{array}{c}0.003 \\
(0.354)\end{array}$ & $\begin{array}{c}-0.001 \\
(-11.184)^{* * *}\end{array}$ & $\begin{array}{c}0.989 \\
(194.4)^{* * *}\end{array}$ \\
\hline INSTI & $\begin{array}{c}0.001 \\
(0.346)\end{array}$ & $\begin{array}{c}0.001 \\
(1.264)\end{array}$ & $\begin{array}{c}-0.001 \\
(-0.861)\end{array}$ & $\begin{array}{c}-0.001 \\
(-1.014)\end{array}$ & $\begin{array}{c}-0.001 \\
(-0.964)\end{array}$ \\
\hline FOREN & $\begin{array}{c}0.006 \\
(3.856) * * *\end{array}$ & $\begin{array}{c}0.001 \\
(1.607)\end{array}$ & $\begin{array}{c}0.002 \\
(2.870)^{* * *}\end{array}$ & $\begin{array}{c}0.001 \\
(1.130)\end{array}$ & $\begin{array}{c}-0.001 \\
(-3.240)^{* * *}\end{array}$ \\
\hline
\end{tabular}




\begin{tabular}{|c|c|c|c|c|c|}
\hline OWN & $\begin{array}{c}-0.002 \\
(-1.756 *\end{array}$ & $\begin{array}{c}-0.001 \\
(-1.943)^{*}\end{array}$ & $\begin{array}{c}0.001 \\
(0.669)\end{array}$ & $\begin{array}{c}0.001 \\
(0.772)\end{array}$ & $\begin{array}{c}0.001 \\
(0.444)\end{array}$ \\
\hline IDUM & Yes & Yes & Yes & Yes & Yes \\
\hline Adj-R $R^{2}$ & 0.179 & 0.164 & 0.144 & 0.511 & 0.996 \\
\hline F-value & $4.541 * * *$ & $3.947 * * *$ & $3.541 * * *$ & $16.731 * * *$ & $3570.5^{* * *}$ \\
\hline
\end{tabular}

$* * *, * *$, and $*$ indicate statistical significance at the $1 \%, 5 \%$, and $10 \%$ levels, respectively. See Table 2 for definitions of variables.

The $t$-values are in parentheses.

The coefficient of the deferred compensation system in the regression of ROA is 0.007 with a $t$-value of 1.756 , which is statistically significant at the $10 \%$ level. This result supports Hypothesis 1-2. The impacts of the deferred compensation system on sales growth (GROWTH) and labor productivity (PRODT) are positive as predicted, but they are not statistically significant. Its impact on expenses (LNEXPENSE) is negative as predicted, but it is also not statistically significant.

When analyses are performed for the whole sample that includes "extreme" firms, the coefficients of the deferred compensation system have the same predicted signs as the coefficients from the "adjusted" sample for all dependent variables. The impact of the deferred compensation system on ROA is statistically significant at the $1 \%$ level with a $t$-value of 2.611. Its impact on labor productivity (PRODT) is also statistically significant at the $1 \%$ level with a $t$-value of 2.562 . These results from the full sample are consistent with Hypotheses 1-2 and 1-4.

The performance-based compensation system, on the other hand, does have a significant effect on sales growth (GROWTH). The coefficient is 0.044 with a $t$-value of 2.162, which is significant at the 5\% level. The results support Hypothesis 2-3. The effects of the performance-based compensation system on the other three factors, however, are not statistically significant.

These results imply that, while both the deferred compensation system and the performance-based compensation system have positive effects on firm value in general, the nature of these positive effects may be different. The empirical results from the adjusted sample and the full sample suggest that the deferred compensation system improves profitability and labor productivity. These results are expected because the deferred compensation system tries to replicate the effects of bonding. The bonding system was originally designed to prevent moral hazard and opportunistic behavior. Under this system, employees are expected to reduce unproductive actions. Therefore, if the system works as expected, productivity will be improved. This will lead to an improvement in profitability. However, the bonding system is not designed to stimulate creative activities, so it may not lead to sales growth.

On the other hand, the empirical results indicate that the incentives provided by the performance-based compensation system enhance firm value through sales maximization. While it is natural that compensation is based on sales growth, there is no a priori reason why compensation cannot be based on improvement in productivity 
or profitability. These empirical results, however, are consistent with our survey of HR managers. Most performance-based compensation systems in Korean firms actually base performance compensation on sales or net income in absolute terms, not on profitability or productivity. We believe that this result reflects common practice in Korea. Korean firms used to place more emphasis on size than profitability, but since the financial crisis of 1997, profitability has been the greater focus. It is possible that a link between the performance-based compensation system and profitability or productivity can be found in future research with more recent data.

Overall, the analysis with value-relevant factors as dependent variables supports the notion that the deferred compensation system can be used to improve profitability and productivity, and the performance-based compensation system can be used to generate growth.

\section{Conclusions}

This study uses regression modeling to test for a significant positive relationship between firm value measured by Tobin's Q and two incentive systems, namely the deferred compensation system and the performance-based compensation system. The existence of such a relationship would be evidence that the management of Korean firms believes that such contracting arrangements are effective vehicles for controlling employee moral hazard. Wage data and performance-based compensation data from 215 Korean firms for the years 1999 and 2000 are used to empirically assess the significance of the relationship. Both the deferred compensation system and the performance-based compensation system are found to have a positive relationship with firm value, thereby supporting the proposition that these contracting arrangements are used to control the problem of moral hazard in Korean firms.

Even though both the deferred compensation system and the performance-based compensation system have positive effects on firm value, the way they affect firm value should differ depending on the characteristics and environments of firms. Additional analyses indicate that the deferred compensation system has positive relationships with return on assets and labor productivity, while the performance-based compensation system has a positive relationship with sales growth.

Previous studies of the agency problem in relation to firm value mostly focused on the simple relationship between firm value and ownership structure. Those studies that examined the effect of compensation on firm value only analyzed top management compensation. This paper has extended the findings of these earlier studies on the effectiveness of incentive systems by using firm-specific empirical wage data drawn from different levels of the organization. 


\section{REFERENCES}

Agrawal, A. and C.R. Knoeber, 1996, "Firm Performance and Mechanisms to Control Agency Problems between Managers and Shareholders", Journal of Financial and Quantitative Analysis 31, 377-398.

Bai, C., Q. Liu, J. Lu, F.M. Song and J. Zhang, 2003, "Corporate Governance and Market Valuations in China", Working Paper, The University of Hong Kong.

Bauer, R., N. Gunster and R. Otten, 2003, "Empirical Evidence on Corporate Governance in Europe: The Effect on Stock Returns, Firm Value and Performance", Working Paper, Maastricht University, Erasmus University Rotterdam.

Black, B.S., H. Jang and W. Kim, 2006, "Does Corporate Governance Predict Firms' Market Values? Evidence from Korea", Journal of Law, Economics and Organization 22, 366-413.

Chen, C.R. and T.L. Steiner, 2000, “Tobin's Q, Managerial Ownership and Analyst Coverage", Journal of Economics and Business 52, 365-382.

Cho, M., 1998, "Ownership Structure, Investment and Corporate Value: An Empirical Analysis", Journal of Financial Economics 47, 103-122.

Core, J., W. Guay and A. Buskirk, 2003, "Market Valuations in the New Economy: An Investigation of What Has Changed", Journal of Accounting and Economics 34, 43-67.

Douglas, E.J. and R.E. Santerre, 1990, "Incentive Contracts and Stockholders Monitoring: Substitute Sources of Executive Compliance", Quarterly Review of Economics and Business 30, 24-31.

Fan, J.P.H. and T.J. Wong, 2002, "Corporate Ownership Structure and the Informativeness of Accounting Earnings in East Asia", Journal of Accounting and Economics 33, 401-425.

Grossman, S.J. and O.D. Hart, 1980, "Takeover Bids, the Free-Rider Problem and the Theory of the Corporation", Bell Journal of Economics 11, 42-64.

Jensen, M.C. and W.H. Meckling, 1976, "Theory of the Firm: Managerial Behavior, Agency Costs and Ownership Structure”, Journal of Financial Economics 3, 305360.

Joh, S.W., 2003, "Corporate Governance and Firm Profitability: Evidence from Korea before the Economic Crisis", Journal of Financial Economics 68, 287-322.

Kaplan, S.N., 1994, "Top Executive Rewards and Firm Performance: A Comparison of Japan and the United States", Journal of Political Economy 102, 510-546.

Korean Productivity Center, 2006, The Analysis of the Value Added of Listed Companies, (Korean Productivity Center: Seoul).

Lazear, E.P., 1979, "Why is There Mandatory Retirement?", Journal of Political Economy 87, 1261-1284.

Lazear, E.P., 1981, “Agency, Earnings Profiles, Productivity and Hours Restrictions", American Economic Review 71, 606-620.

Lazear, E.P., 1998, Personnel Economics for Managers (John Wiley \& Sons: New York).

Lindenberg, E.B. and S.A. Ross, 1981, “Tobin's Q Ration and Industrial Organization”, Journal of Business 54, 1-32. 
Mehran, H., 1995, "Executive Compensation Structure, Ownership, and Firm Performance", Journal of Financial Economics 38, 163-184.

Milgrom, P. and J. Roberts, 1992, Economics, Organization and Management (Prentice Hall: Englewood Cliffs, NJ).

Morck, R., A. Shleifer and R.W. Vishny, 1988, "Management Ownership and Market Valuation: An Empirical Analysis", Journal of Financial Economics 20, 293-315.

Ross, A.S., 1977, "The Determination of Financial Structure: The Incentive Signaling Approach", Bell Journal of Economics 8, 23-40.

Stulz, R., 1988, "Managerial Control of Voting Rights: Financing Policies and the Market for Corporate Control", Journal of Financial Economics 20, 25-54.

The Bank of Korea, 2006, Financial Statement Analysis for 2005 (The Bank of Korea: Seoul). 


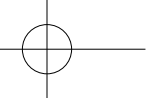

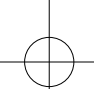

